\title{
Efek Parasetamol Intravena terhadap Regresi Sensorik Anestesi Spinal dengan Bupivakain Hiperbarik 0,5\%
}

\author{
Hadi Sumitro Jioe, Maribelle A. Reyes \\ Departemen Anestesiologi Departemen Kesehatan-East Avenue Medical Center, \\ Metro Manila, Filipina
}

\begin{abstract}
Abstrak
Penggunaan anestesi spinal untuk operasi besar saat ini umum dilakukan dan telah dipraktikkan dalam jangka waktu cukup lama. Parasetamol merupakan obat analgetik yang telah dikenal cukup lama dan saat ini digunakan untuk mengontrol nyeri baik selama operasi maupun pascaoperasi. Parasetamol memiliki efek analgetik pada susunan saraf pusat (SSP) melalui penghambatan jalur siklo-oksigenase dan berpengaruh secara tidak langsung terhadap sistem serotoninergik serta ditemukan dalam konsentrasi yang signifikan dalam cairan serebrospinal setelah pemberian melalui infus. Penelitian ini bertujuan mengevaluasi pengaruh pemberian parasetamol intravena dosis tunggal sebelum operasi terhadap regresi blok anestesi spinal pada pasien yang akan dilakukan operasi besar. Sebanyak 30 pasien dengan klasifikasi American Society of Anesthesiologist (ASA) I dan II dengan rentang usia 18-55 tahun yang dilakukan operasi besar dengan anestesi spinal diikutsertakan ke dalam uji acak terkontrol buta ganda yang dilakukan periode FebruariJuni 2015 di Operating Theatre-East Avenue Medical Center, Quezon City, Philippines. Pasien dialokasikan menjadi 2 grup secara acak dan diberikan infus $100 \mathrm{~mL}$ parasetamol 1 gram (Grup A; $\mathrm{n=15}$ ) atau $100 \mathrm{~mL}$ $\mathrm{NaCl}$ 0,9\% (Grup P; $\mathrm{n}=15$ ) selama 20 menit sebelum pemberian obat pada anestesi spinal. Penilaian nyeri dinilai menggunakan visual analog scale (VAS), serta dicatat pada saat diberikan bantuan obat analgetik. Data dianalisis dengan uji chi-kuadrat dengan nilai $\mathrm{p}<0,05$ dianggap bermakna. Regresi blok sensorik tertunda secara signifikan pada Grup A pada jam ke-2 (T5-T7; n=11) dibanding dengan grup P pada jam ke-2 (T5-T7; $n=2$ ) dengan nilai $p<0,05$. Simpulan, pemberian infus parasetamol intravena 20 menit sebelum dilakukan anestesi spinal dengan bupivakain hiperbarik 0,5\% dapat menunda regresi blok sensorik.
\end{abstract}

Kata kunci: Anestesi spinal, bupivakain hiperbarik, parasetamol intravena, regresi sensorik

\section{Effect of Intravenous Paracetamol on Sensory Regression of Spinal Anesthesia with Bupivacaine Heavy $0.5 \%$}

\begin{abstract}
Spinal anesthesia is a long-accepted anesthesia that is commonly used for major surgery. Paracetamol intravenous infusion is a known analgesics that is recently used for intra-operative as well as post-operative pain control. Paracetamol has an analgesic effect, primarily to the central nervous system (CNS), through the cyclooxygenase pathway, and probably has an indirect influence on the serotoninergic system which is supported by the fact that paracetamol is found in significant concentration in the cerebrospinal fluid (CSF) after infusion. This study was designed to evaluate the effect of single pre-operative intravenous infusion of paracetamol on sensory regression of spinal blockade in patients undergoing major surgery. Thirty ASA I and II patients aged 18-55 years undergoing major surgery under spinal anesthesia were included in this randomized controlled trial double blind study during the period of February-June 2015 at the Operating Theatre - East Avenue Medical Center, Philippines. Patients were randomly allocated to receive either 1 gr/100 mL Paracetamol (Group A; n=15) or 100 mL Normal Saline (Group P; n=15) drip for 20 minutes before administration of spinal anesthesia. The intensity of pain was assessed by Visual Analog Scale (VAS) Score. Time of rescue analgesic administration was also recorded. Data were analyzed by Chi-Square Test with $\mathrm{p}$ value of $<0.05$ considered significant. Sensory regression was delayed in Group A (T5 - T7; $\mathrm{n}=11$ ) when compared to Group P (T5 - T7; $n=2)$, which was statistically significant $(\mathrm{p}<0.05)$. Therefore, the administration intravenous Paracetamol 20 minutes prior to spinal anesthesia administration with Bupivacaine Heavy $0.5 \%$ can delay regression of sensory blockade.
\end{abstract}

Keywords: Bupivacaine heavy, intravenous paracetamol, sensory regression, spinal anesthesia

Korespondensi: Hadi Sumitro Jioe, Anesthesiology Department, Department of Health Hospital, East Avenue Medical Center East Avenue, Diliman, Quezon City, 1100 Metro Manila Phone (+63) 29280611 local 441 and (+63) 29253122 Cellphone (+63) 9052807505 / (+62) 812228 2853, Email: hadijioe@gmail.com 


\section{Pendahuluan}

Anestesi spinal merupakan salah satu teknik anestesi yang dipakai untuk operasi besar dalam jangka waktu lama. Berbagai adjuvan telah digunakan untuk memperpanjang durasi anestesi lokal pada teknik anestesi spinal. Obat yang sering kali digunakan sebagai adjuvan adalah golongan opioid karena terbukti memiliki efek analgetik pada susunan saraf pusat (SSP). Akan tetapi, efek samping golongan opioid seperti sedasi yang berlebihan, perlambatan pengosongan isi lambung, retensi urine, pruritus, mual, muntah, dan depresi sistem pernapasan menyebabkan obat tersebut dibatasi penggunaannya. ${ }^{1}$

Studi pada 6.000 pasien mengemukakan peningkatan efek samping akibat pemberian opioid intratekal dosis kecil sesaat setelah pemberian anestesi spinal meskipun insidensi tersebut masih tergolong rendah. Pemberian opioid intratekal dosis rendah yang bersifat lipofilik dapat menyebabkan depresi napas onset cepat (0-1 jam), sementara pemberian opioid intratekal dosis rendah yang bersifat hidrofilik dapat menyebabkan depresi napas onset lambat (hingga 24 jam pascaoperasi). Morfin intratekal dapat menyebabkan depresi napas setelah 3,5-12 jam setelah pemberian dengan puncak pada jam ke-6. Meperidin (petidin) bersifat hiperbarik apabila diberikan secara intratekal dengan dosis $0,5 \mathrm{mg}$ dapat menyebabkan blok spinal tinggi sesaat setelah pemberian sehingga menyebabkan opioid ini tidak dipergunakan secara intratekal. ${ }^{2}$

Parasetamol ditemukan tahun 1878 oleh Morse dan mulai dipergunakan di dunia kedokteran pada tahun 1893. Parasetamol digunakan untuk manajemen nyeri pada saat operasi atau pascaoperasi baik secara per oral, rektal, maupun parenteral. ${ }^{1}$

Parasetamol bekerja pada susunan saraf pusat melalui penghambatan jalur siklooksigenase $^{3,4}$ dan penghambatan nyeri supraspinal melalui jalur serotoninergik, ${ }^{5}$ secara tidak sengaja parasetamol ditemukan dalam konsentrasi yang signifikan dalam cairan serebrospinal setelah pemberian melalui infus pada dewasa dan anak. ${ }^{6}$ Interaksi sinergis antara parasetamol dan anestestik lokal telah diobservasi pada penelitian sebelumnya bahwa pemberian parasetamol selama intravenous regional anesthesia (IVRA) dengan lidokain dapat menurunkan nyeri akibat turniket, meningkatkan kualitas anestesi, dan menurunkan konsumsi analgetik pascaoperasi. Suhubungan dengan fakta bahwa parasetamol ditemukan dalam konsentrasi yang signifikan dalam cairan serebrospinal serta terdapat interaksi sinergis antara parasetamol dan anestestik lokal dalam meningkatkan kualitas anestesi maka peneliti berinisiatif melakukan penelitian ini. ${ }^{7,8}$

Peneliti menggunakan parasetamol intravena sebagai adjuvan pada pemberian anestesi spinal dengan bupivakain hiperbarik $0,5 \%$. Penelitian ini bertujuan mengetahui efek parasetamol intravena dalam menunda regresi sensorik anestesi spinal dengan bupivakain hiperbarik $0,5 \%$ sehingga meningkatkan kualitas anestesi.

\section{Subjek dan Metode}

Penelitian ini merupakan penelitian eksperimental dengan uji acak terkontrol buta ganda pada pasien yang dilakukan pembedahan dengan anestesi spinal di East Avenue Medical Center, Quezon City, Philippines pada periode Februari-Juni 2015. Kriteria inklusi subjek penelitian adalah pasien yang menjalani prosedur pembedahan mayor, usia 18-55 tahun, status fisik American Society of Anesthesiologist (ASA) kelas I-II. Kriteria eksklusi, yaitu subjek menolak untuk dilakukan anestesi spinal, infeksi kulit di lokasi penusukan anestesi spinal, alergi terhadap bupivakain hiperbarik 0,5\% dan parasetamol, tekanan darah tinggi tidak terkontrol, diabetes melitus tipe II tidak terkontrol, asma bronkiale eksaserbasi akut, serta kelainan hati, ginjal, jantung, dan paru. Kriteria pengeluaran adalah gagal blok spinal atau blok tidak adekuat.

Penentuan besar sampel menggunakan rumus untuk penelitian analisis kategorik numerik berpasangan dengan menetapkan taraf kepercayaan 95\% dan uji kuasa (power test) $95 \%$ didapatkan jumlah sampel minimal 
30 pasien. Pemilihan subjek penelitian berdasar atas consecutive sampling, yaitu mengambil subjek penelitian yang memenuhi kriteria inklusi dan tidak termasuk kriteria eksklusi berdasar atas urutan kedatangan subjek. Subjek penelitian terdiri atas 30 pasien yang dibagi menjadi dua kelompok dengan cara randomisasi menggunakan blok permutasi, yaitu kelompok parasetamol (A) dan kelompok plasebo (B). Dilakukan pengacakan menggunakan generator bilangan acak pada komputer untuk memasukkan pasien ke dalam salah satu kelompok.

Penelitian dimulai setelah mendapat persetujuan dari Komite Etik East Avenue Medical Center. Pasien yang memenuhi kriteria inklusi diberikan penjelasan dan menandatangani persetujuannya (informed consent) tentang penelitian. Akses intravena dimasukkan menggunakan kanul ukuran 18G dan 20G. Monitor rutin sesuai dengan standar ASA seperti elektrokardiogram, alat pengukur tekanan darah noninvasif, dan oksimetri digunakan untuk memonitor semua pasien. Anestesi spinal diberikan menggunakan jarum spinocaine tipe Quincke ukuran 25G atau 26G pada ruang interspinal L3-L4 menggunakan teknik standar midline atau paramedian dengan posisi lateral dekubitus menggunakan larutan $4 \mathrm{~mL}(0,5 \%, 20 \mathrm{mg})$ bupivakain hiperbarik.

Grup A mendapatkan infus parasetamol intravena sebanyak $1 \mathrm{~g} / 100 \mathrm{~mL}$ dalam waktu 20 menit dan grup B mendapatkan infus $\mathrm{NaCl}$ 0,9\% sebanyak $100 \mathrm{~mL}$ sebagai plasebo dalam waktu 20 menit sebelum induksi anestesi spinal. Larutan diberikan pada pasien dalam botol yang telah disegel dan diberi nomor sesuai dengan generator bilangan acak sebelumnya oleh dokter anestesi yang tidak terlibat dalam penelitian ini. Pasien dan dokter anestesi tersebut tidak mengetahui terhadap perlakuan penelitian ini. Blok sensorik dievaluasi menggunakan tes pinprick atau apus alkohol pada linea mid-axillaris secara bilateral dengan arah dari cephalad menuju caudal menggunakan jarum sekali pakai pada menit ke-10 dan 30, serta jam ke-1, 2, dan 3 setelah pemberian anestesi, kemudian dilakukan analisis dermatomal mengenai distribusi blok sensorik. Nyeri selama operasi dievaluasi menggunakan visual analog scale (VAS) dengan skala 0 = tidak ada nyeri; $1-3$ = nyeri ringan; $4-6=$ nyeri sedang; $7-9=$ nyeri berat, $10=$ nyeri hebat). Durasi blok sensorik dihitung sejak mencapai ketinggian T4 secara dermatomal (setinggi papilla mammae) sampai dibutuhkan pemberian dosis tambahan analgetik atau VAS lebih atau sama dengan 4/10. Blok motorik dievaluasi menggunakan modified bromage scale yang digunakan oleh Breen dkk. Dilakukan juga pencatatan saat pemberian obat analgetik pertama pascaoperasi. Apabila didapatkan pasien dengan VAS lebih atau sama dengan 4/10 pascaoperasi maka diberikan obat analgetik tambahan (nalbuphine 0,5 mg IV atau butorphanol $1 \mathrm{mg}$ IV atau natrium diklofenak $75 \mathrm{mg}$ IV atau ketorolak $30 \mathrm{mg}$ IV atau obat analgetik lain dengan dosis ekuianalgetik).

Data dianalisis menggunakan statistical product and servise solution (SPSS) version 20.0. Usia, tinggi badan, berat badan, durasi operasi, onset dari blok sensorik dan motorik, dan waktu pemberian obat analgetik tambahan dibandingkan dengan menggunakan uji t tidak berpasangan.

Statistik deskriptif untuk variabel kualitatif seperti jenis kelamin, ASA, dan prosedur operasi dinyatakan dalam bentuk frekuensi dan persentase, serta digunakan standar deviasi dan rerata untuk variabel kuantitatif.

\section{Hasil}

Penelitian ini dilakukan terhadap 30 pasien yang dibagi dalam 2 grup ( $n=15$ untuk grup parasetamol dan $\mathrm{n}=15$ untuk grup plasebo). Gambaran karakteristik subjek penelitian berdasar atas usia, jenis kelamin, status fisik ASA, tinggi badan, dan berat badan antara kedua kelompok penelitian tidak terdapat perbedaan yang bermakna ( $p>0,05$; Tabel 1 ).

Hasil penelitian menunjukkan bahwa onset blok sensorik dan motorik pada kedua kelompok tidak berbeda signifikan $(\mathrm{p}>0,05$; Tabel 2).

Hasil penelitian menunjukkan bahwa 
Tabel 1 Karakteristik Subjek Penelitian

\begin{tabular}{|c|c|c|c|}
\hline Karakteristik & $\begin{array}{c}\text { Grup A } \\
\text { Parasetamol } \\
(n=15)\end{array}$ & $\begin{array}{c}\text { Grup B } \\
\text { Plasebo } \\
(n=15)\end{array}$ & Nilai p \\
\hline \multicolumn{4}{|l|}{ Jenis kelamin } \\
\hline Pria & 6 & 5 & \multirow{2}{*}{0,705} \\
\hline Wanita & 9 & 10 & \\
\hline \multicolumn{4}{|l|}{ ASA } \\
\hline I & 6 & 9 & \multirow{2}{*}{0,273} \\
\hline II & 9 & 6 & \\
\hline \multicolumn{4}{|l|}{ Usia (tahun) } \\
\hline Mean & $35,13 \pm 7,96$ & $33,60 \pm 9,08$ & \multirow{3}{*}{0,627} \\
\hline Median & 33 & 32 & \\
\hline Range (min.-maks.) & $22-51$ & $21-50$ & \\
\hline \multicolumn{4}{|l|}{ Tinggi badan $(\mathrm{cm})$} \\
\hline Mean & $161,40 \pm 13,09$ & $159,80 \pm 10,99$ & \multirow{3}{*}{0,720} \\
\hline Median & 161 & 160 & \\
\hline Range (min.-maks.) & $130-181$ & $137-175$ & \\
\hline \multicolumn{4}{|l|}{ Berat badan (kg) } \\
\hline Mean & $61,27 \pm 10,07$ & $57,40 \pm 7,98$ & \multirow{3}{*}{0,254} \\
\hline Median & 60 & 60 & \\
\hline Range (min.-maks.) & $48-80$ & $45-70$ & \\
\hline \multicolumn{4}{|l|}{ Jenis operasi } \\
\hline Apendektomi & 4 & 4 & \\
\hline Laparatomi eksplorasi & 2 & 2 & \\
\hline Histerektomi total & 3 & 1 & \\
\hline Hernioplasti & 2 & 2 & \\
\hline Salpingektomi & 2 & 4 & \\
\hline Salpingostomi & 0 & 1 & \\
\hline Salpingo-ooforektomi & 1 & 0 & \\
\hline Laparotomi mini & 1 & 0 & \\
\hline Reparasi prolaps uteri & 0 & 1 & \\
\hline
\end{tabular}

Keterangan: data numerik nilai p diuji dengan uji-t tidak berpasangan apabila data berdistribusi normal dan alternatif Uji Mann Whitney apabila data tidak berdistribusi normal. Nilai kemaknaan berdasar atas nilai $\mathrm{p}<0,05$.

Tanda * menunjukkan nilai $\mathrm{p}<0,05$ artinya signifikan atau bermakna secara statistik

distribusi ketinggian blok setelah 2 jam pemberian lokal anestestik lebih tinggi pada grup A dibanding dengan grup $B$ dan distribusi ketinggian blok setelah 3 jam dari pemberian lokal anestestik lebih tinggi pada grup A dibanding dengan grup B dengan perbedaan yang bermakna secara statistik $(p<0,05$; Tabel
$3)$.

Hasil penelitian menunjukkan bahwa skala modifikasi bromage (Breen dkk.) 1-2 setelah 3 jam dari pemberian lokal anestesi lebih tinggi pada grup A dibanding dengan grup B dengan perbedaan yang bermakna secara statistik $(\mathrm{p}<0,05$; Tabel 4). 
Tabel 2 Waktu Blok Sensorik dan Motorik Tercapai

\begin{tabular}{lccc}
\hline & $\begin{array}{c}\text { Grup A } \\
\text { Parasetamol } \\
(\mathbf{n = 1 5})\end{array}$ & $\begin{array}{c}\text { Grup B } \\
\text { Plasebo } \\
\text { (n=15) }\end{array}$ & Nilai p \\
\hline Waktu hingga blok sensorik T4 tercapai (menit) & $5,60 \pm 3,01$ & $6,66 \pm 3,51$ & 0,380 \\
Waktu hingga blok motorik komplit (menit) & $7,06 \pm 3,23$ & $6,46 \pm 2,89$ & 0,597 \\
\hline
\end{tabular}

Keterangan: data numerik nilai p diuji dengan uji-t tidak berpasangan apabila data berdistribusi normal dan alternatif Uji Mann Whitney apabila data tidak berdistribusi normal. Nilai kemaknaan berdasar atas nilai p<0,05. Tanda * menunjukkan nilai $\mathrm{p}<0,05$ artinya signifikan atau bermakna secara statistik

Hasil penelitian menunjukkan bahwa nilai VAS 0-3 pada pengukuran 1 jam, 2 jam, dan 3 jam pada grup A lebih banyak dibanding dengan grup B. Hasil tersebut tidak bermakna secara statistik ( $p>0,05$; Tabel 5).

Hasil penelitian menunjukkan bahwa rerata waktu pemberian analgetik pertama pada grup A adalah 2,99 $\pm 0,86$ jam bila dibanding dengan grup B adalah 2,91 $\pm 1,01$ jam. Hasil tersebut tidak bermakna secara statistik $(p>0,05)$.

\section{Pembahasan}

Parasetamol intravena berbahan dasar air (1 g/100 mL) diperkenalkan sejak tahun 2002

Tabel 3 Distribusi Ketinggian Blok Sensorik pada Kedua Grup terhadap Waktu

\begin{tabular}{lccccccccccc}
\hline & \multicolumn{10}{c}{ Dermatom Sensorik } & \\
\cline { 2 - 9 } Waktu & \multicolumn{8}{c}{ Grup A (Parasetamol; n=15) } & \multicolumn{7}{c}{ Grup B (Plasebo; n=15) } \\
\cline { 2 - 10 } & T2- & T5- & T8- & T11- & L2-L4 & T2- & T5-T7 & T8- & T11- & L2- & \\
& T4 & T7 & T10 & L1 & L10 & L1 & L4 & \\
\hline 10 menit & 15 & 0 & 0 & 0 & 0 & 15 & 0 & 0 & 0 & 0 & - \\
30 menit & 15 & 0 & 0 & 0 & 0 & 15 & 0 & 0 & 0 & 0 & - \\
1 jam & 10 & 5 & 0 & 0 & 0 & 4 & 10 & 1 & 0 & 0 & 0,073 \\
2 jam & 0 & 11 & 4 & 0 & 0 & 0 & 2 & 9 & 4 & 0 & $0,002^{*}$ \\
3 jam & 0 & 3 & 11 & 1 & 0 & 0 & 2 & 0 & 5 & 8 & $0,000^{*}$ \\
\hline
\end{tabular}

Keterangan: data numerik nilai p diuji dengan uji chi-kuadrat. Nilai kemaknaan berdasar atas nilai $p<0,05$. Tanda * menunjukkan nilai $\mathrm{p}<0,05$ artinya signifikan atau bermakna secara statistik

Tabel 4 Skala Modifikasi Bromage (Breen dkk.) pada Kedua Grup terhadap Waktu

\begin{tabular}{|c|c|c|c|c|c|c|c|}
\hline \multirow{3}{*}{ Waktu } & \multicolumn{6}{|c|}{ Skala Modifikasi Bromage } & \multirow{3}{*}{ Nilai p } \\
\hline & \multicolumn{3}{|c|}{ Grup A (Parasetamol; $n=15$ ) } & \multicolumn{3}{|c|}{ Grup P (Plasebo; n=15) } & \\
\hline & 1-2 & $3-4$ & $5-6$ & $1-2$ & $3-4$ & $5-6$ & \\
\hline 10 menit & 15 & 0 & 0 & 15 & 0 & 0 & - \\
\hline 30 menit & 15 & 0 & 0 & 15 & 0 & 0 & - \\
\hline 1 jam & 15 & 0 & 0 & 15 & 0 & 0 & - \\
\hline 2 jam & 12 & 3 & 0 & 15 & 0 & 0 & 0,068 \\
\hline 3 jam & 12 & 1 & 2 & 8 & 7 & 0 & $0,026^{*}$ \\
\hline
\end{tabular}

Keterangan: data numerik nilai p diuji dengan uji chi-kuadrat. Nilai kemaknaan berdasar atas nilai $\mathrm{p}<0,05$. Tanda * menunjukkan nilai $\mathrm{p}<0,05$ artinya signifikan atau bermakna secara statistik 
Tabel 5 Skala Visual Analog pada Kedua Grup

\begin{tabular}{|c|c|c|c|c|c|c|c|}
\hline \multirow{3}{*}{ Waktu } & \multicolumn{6}{|c|}{ Skala Visual Analog } & \multirow{3}{*}{ Nilai p } \\
\hline & \multicolumn{3}{|c|}{ Grup A (Parasetamol; n=15) } & \multicolumn{3}{|c|}{ Grup B (Plasebo; n=15) } & \\
\hline & 0-3 & $4-6$ & $7-10$ & $0-3$ & $4-6$ & $7-10$ & \\
\hline 10 menit & 15 & 0 & 0 & 15 & 0 & 0 & - \\
\hline 30 menit & 15 & 0 & 0 & 15 & 0 & 0 & - \\
\hline 1 jam & 15 & 0 & 0 & 14 & 1 & 0 & 0,542 \\
\hline 2 jam & 14 & 0 & 1 & 11 & 1 & 3 & 0,141 \\
\hline $3 \mathrm{jam}$ & 14 & 0 & 1 & 10 & 2 & 3 & 0,067 \\
\hline
\end{tabular}

Keterangan: data numerik nilai p diuji dengan uji chi-kuadrat. Nilai kemaknaan berdasar atas nilai $\mathrm{p}<0,05$. Tanda * menunjukkan nilai $\mathrm{p}<0,05$ artinya signifikan atau bermakna secara statistik

merupakan obat analgetik golongan nonopioid baru yang relatif mudah didapatkan dan menjanjikan. Konsentrasi puncak plasma tercapai dalam waktu kurang lebih 15 menit setelah pemberian secara intravena. Efek analgetik maksimum terjadi 1-2 jam setelah konsentrasi puncak plasma tercapai. Pada penelitian ini parasetamol intravena diberikan 15-20 menit sebelum penusukan jarum spinal dan pemberian parasetamol dilakukan secara perlahan selama 15 menit. Data karakteristik subjek penelitian yang dibandingkan pada kedua grup menunjukkan perbedaan yang tidak bermakna pada usia, berat badan, dan tinggi badan. Data ini sangat diperlukan karena berpengaruh pada metabolisme obat lokal anestesi dan analgesi seperti usia berpengaruh pada kemampuan tubuh untuk metabolisme obat. Berat badan berpengaruh terhadap dosis maksimum obat yang dapat diberikan serta tinggi badan berpengaruh pada jumlah obat yang diperlukan untuk mencapai ketinggian blok tertentu. Data penelitian ini menunjukkan bahwa sampel yang diambil dalam penelitian ini homogen (Tabel 1) sehingga layak untuk dibandingkan. ${ }^{1}$

Pada penelitian ini dilakukan uji terhadap pemberian parasetamol intravena terhadap efek anestesi lokal yang diberikan secara intratekal sehubungan dengan fakta bahwa parasetamol ditemukan dalam konsentrasi yang signifikan dalam cairan serebrospinal setelah pemberian melalui infus pada dewasa dan anak. Onset lokal anestesi dibandingkan terlebih dahulu sebelum dimulai penilaian efek parasetamol dalam meningkatkan kualitas anestetik lokal dengan cara menghambat sensory regression. Data penelitian menunjukkan bahwa pada kedua grup (Tabel 2), waktu tercapainya blok sensorik setinggi T4 pada grup A adalah 5,60 $\pm 3,01$ menit dibanding dengan waktu tercapainya blok sensorik setinggi $\mathrm{T} 4$ pada grup $\mathrm{P}$ adalah $6,66 \pm 3,51$ menit dan waktu tercapainya blok motorik komplet (skala modifikasi Bromage 1) pada grup $A$ adalah $7,06 \pm 3,23$ menit dibanding dengan waktu tercapainya blok motorik komplet (skala modifikasi Bromage 1) grup P adalah $6,46 \pm 2,89$ menit. Onset pada kedua grup tidak menunjukkan perbedaan yang bermakna sehingga pengukuran dapat dilakukan secara akurat. ${ }^{6-8}$

Pada penelitian didapatkan bahwa pada grup A terdapat 11 pasien yang memiliki ketinggian blok setinggi T5-T7 setelah 2 jam berlalu sejak pemberian bupivakain hiperbarik $0,5 \%$ dibanding dengan grup $\mathrm{P}$ terdapat 2 pasien yang memiliki ketinggian blok setinggi T5-T7 setelah 2 jam berlalu sejak pemberian bupivakain hiperbarik 0,5\%. Terdapat 11 pasien yang memiliki ketinggian blok setinggi T8-T10 setelah 3 jam berlalu sejak pemberian bupivakain hiperbarik 0,5\% dibanding dengan grup $\mathrm{P}$ tidak terdapat pasien yang memiliki ketinggian blok setinggi T8-T10 setelah 3 jam berlalu sejak pemberian bupivakain hiperbarik 0,5\% (Tabel 3). Efek analgesik parasetamol diduga berhubungan 
dengan aktivasi secara tidak langsung dari reseptor cannabinoid (CB1). .10

Parasetamol dimetabolisme pada otak dan susunan saraf pusat (SSP) membentuk $\mathrm{N}$-arachidonylphenolamine (AM404).

$\mathrm{N}$-arachidonylphenolamine menghambat serapan anandamide, sebuah endocannabinoid secara seluler dan merupakan agonis reseptor vanilloid (TRPV1) yang dipercaya merupakan sentral pada persepsi untuk nyeri nosiseptif. ${ }^{11}$ Penelitian terbaru mengenai pemberian parasetamol intravena untuk mengurangi nyeri yang disebabkan oleh pemberian propofol secara intravena ${ }^{12}$ membuktikan bahwa parasetamol mempunyai efek antinosiseptif di perifer.

Parasetamol diperkirakan bekerja melalui beberapa jalur yang berbeda. Pertama, telah terbukti bahwa parasetamol menurunkan sintesis prostaglandin melalui penghambatan lemah jalur siklo-oksigenase, ${ }^{3,4}$ baik secara perifer ${ }^{13}$ maupun sentral. ${ }^{14}$ Kedua, penelitian terhadap binatang membuktikan efek antinosiseptif berhubungan dengan spinal nitric oxide pathways yang berhubungan dengan aktivasi reseptor glutamat $N$-methyl-Daspartate (NMDA) di spinal. ${ }^{15}$ Akhirnya, percobaan nyeri pada manusia maupun binatang, parasetamol terbukti bekerja pada SSP melalui mekanisme serotoninergik. ${ }^{5}$

Efek analgetik setelah pemberian sistemik parasetamol intravena disebabkan oleh aksi sinergestik komponen supraspinal yang menyerupai opioid. Mekanisme supraspinal dan perifer parasetamol inilah yang diduga menunda regresi sensorik pada anestesi spinal. Sebagai tambahan, durasi blok motorik pun ikut terpengaruhi. ${ }^{16}$ Reseptor CB1 mempunyai kontribusi terhadap pembentukan lapisan bagian dalam sel saraf kortikal melalui mekanisme coupling endocannabinoid sehingga memodulasi transkripsi chicken ovoalbumin upstream promoter transcription factor (COUP-TF) interacting protein 2 (Ctip2)/ special AT-rich sequence-binding protein 2 (Satb2) yang berperan dalam diferensiasi sel saraf, selanjutnya berperan dalam mengatur perubahan fungsi motorik. ${ }^{17}$ Penelitian menunjukkan bahwa pada grup A terdapat
12 pasien memiliki skala modifikasi Bromage (Breen dkk.) 1-2 setelah 3 jam berlalu sejak pemberian bupivakain hiperbarik $0,5 \%$ dibanding dengan grup $\mathrm{P}$ terdapat 8 pasien memiliki skala modifikasi Bromage (Breen dkk.) 1-2 setelah 3 jam berlalu sejak pemberian bupivakain hiperbarik $0,5 \%$ (Tabel 4).

Pada penelitian didapatkan waktu regresi sensorik tertunda lebih lama pada grup A dibanding dengan grup $\mathrm{P}$, namun waktu pemberian analgetik pertama pada kedua grup tidak berbeda signifikan. Didapatkan hasil rerata pengukuran VAS lebih rendah pada grup A dibanding dengan grup $\mathrm{P}$ yang mulai terlihat setelah 1 jam pascaoperasi hingga 3 jam pascaoperasi meski perbedaan tersebut tidak bermakna. Hasil tersebut disebabkan oleh regresi sensorik menghasilkan nilai VAS yang memiliki interpretasi derajat nyeri yang sama, yaitu nyeri dengan skala 1-3: nyeri ringan, skala 4-6: nyeri sedang, dan skala 7-10: nyeri berat atau hebat (Tabel 5).

\section{Simpulan}

Parasetamol intravena terbukti meningkatkan kualitas anestesi bupivakain hiperbarik 0,5\% dengan memanjangnya waktu regresi blok sensorik dan sebagai akibatnya komponen motorik pun ikut terpengaruhi. Penelitian menggunakan metode metaanalisis dianjurkan untuk mengetahui efek parasetamol lebih lanjut terhadap lokal anestesi pada anestesi spinal.

\section{Daftar Pustaka}

1. Bhattacharya D, Roy S, Sribastav S, Chanda $\mathrm{R}$, Paul S, Chowdhury G. Intravenous paracetamol infusion can prolong duration of spinal anesthesia in patients undergoing major gynecological surgeries. Int J Sci Nat. 2013;4(1):23-8.

2. Hindle A. Intrathecal opioids in the management of acute postoperative pain. Br J Anaesth. 2008;8(3):81-5.

3. Ayoub SS, Colville-Nash PR, Willoughby DA, Botting RM. The involvement of a cyclo- 
oxygenase 1 gene - derived protein in the antinociceptive action of paracetamol in mice. Eur J Pharmacol. 2006;538:57-65.

4. Mitchell JA, Akarasereenont P, Thiemermann C, Flower RJ, Vane JR. Selectivity of nonsteroidal antiinflammatory drugs as inhibitors of constitutive and inducible cyclooxygenase. Proc Natl Acad Sci. 1993;90:11693-7.

5. Pickering G, Loriot MA, Libert F, Eschalier A, Beaune P, Dubray C. Analgesic effect of acetaminophen in humans: first evidence of a central serotonergic mechanism. Clin Pharmacol Ther. 2006;79:371-8.

6. Kumpulainen E, Kokki H, Halonen T, Heikkinen M, Savolainen J, Laisalmi M. Paracetamol penetrates readily into the cerebrospinal fluid of children after intravenous administration. Pediatrics. 2007;119:766-71.

7. Sen H, Kulahci Y, Bicerer E, Ozkan S, Dagh G, Turan A. The analgesic effect of paracetamol when added to lidocaine for intravenous regional anesthesia. Anesth Analg. 2009;109:1327-30.

8. Saricaoglu CM, Canbay F, Dal O, Uzumcigil D, Leblebicioglu A, Aypar G. The analgesic effect of paracetamol when added to lidocaine for intravenous regional anesthesia. Minerva Anestesiol. 2011.

9. Alessandra O, Sheila L, Maurizio S, Anna F, Alfio B, The analgesic activity of paracetamol is prevented by the blockade of cannabinoid CB1 receptors. Eur J Pharmacol. 2006;531(1-3):280-1.

10. Sandrini M, Pini LA, Vitale G. Differential involvement of central 5-HT1B and 5-HT3 receptor subtypes in the antinociceptive effect of paracetamol. Inflamm Res.
2003;52:347-52.

11. Hogesstat ED, Jonsson BA, Ermund A, Andersson DA, Björk H, Alexander JP. Conversion of acetaminophen to the bioactive $\mathrm{N}$ - acylphenolamine AM404 via fatty acid amide hydrolase - dependent arachidonic acid conjugation in the nervous system. J Biol Chem. 2005;280:31405-12.

12. Borazan H, Erdem TB, Kececioglu M, Otelcioglu S. Prevention of pain on injection of propofol: a comparison of lidocaine with different doses of paracetamol. Eur J Anesth. 2010;27:253-7.

13. Colletti AE, Vogl HW, Rahe T, Zambraski EJ. Effect of acetaminophen and ibuprofen on renal function in anesthetized normal and sodium depleted dogs. J Appl Physiol. 1999;86:592-7.

14. Muth-Selbach US, Tegeder I, Brune K, Geisslinger G. Acetaminophen inhibits spinal prostaglandin E2 release after peripheral noxious stimulation. Anesthesiology. 1999;91:231-9.

15. Bjorkman R. Central antinociceptive effects of non-steroidal anti-inflammatory drugs and paracetamol: experimental studies in the rat. Acta Anaesthesiol Scand. 1995;103(suppl):1-44.

16. Nakayama $Y$, Omote $K$, Kawamata $T$, Namiki A. Role of prostaglandin receptor subtype EP1 in prostaglandin E2-induced nociceptive transmission in the rat spinal dorsal horn. Brain Res. 2004;1010:62-8.

17. Alonso JD, Aguado T, Wu CS, Palazuelos J, Hofmann C, Patricia G. The CB1 cannabinoid receptor drives corticospinal motor neuron differentiation through the Ctip2/Satb2 transcriptional regulation axis. J Neurosci. 2012;32(47):16651-5. 